\title{
未納税取引の現状と今後の方向
}

\author{
清酒の需要停滞の昨今, 未納税取引について種々の問題が起りつつあ

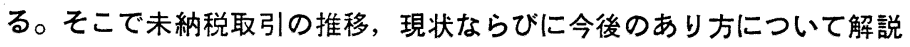 \\ していただいた。
}

一富

忠 雄

清酒需要の停滞のなかで, 最近, 率納税移入企業は可 能な限り自製酒比率を高めたいとの意向を強めてきてい るため, 未納税取引数量は, 昭和 50 年度の 522 千 $\mathrm{k} l$ を ピークとしてその後隇少を続けており, 未納税移出企柴 にとっては厳しい環境下にある。以下,未納税取引の現 状と今妥の方向について解説し参考に供したい。

\section{1. 未納税取引の現状}

\section{（1）未納税移出の推移}

最近に打ける未納税移出の推移は第 1 表のとおりであ る。

全製造場及び未納税移出場数ともに減少の一途を辿っ ているが，全製造場数の減少より未納税移出場数の減少 の方が大きい。即ち, 昭和 48 年度と昭和 55 年度を比 較すると, 全製造場数は 3,351 場が 3,044 場で 307 場 の淢に対し未納税移出場数は 2,565 場から 1,844 場と 721 場の減少となっている。

また, 未納税移出数量は, 昭和 50 年度までは増加の 傾向で推移し, 昭和 50 年度においては 522 千 $k l$ (全製 成数量の $38.3 \%$ ）之史上最高を示したが，その後每年 減少を続け, 昭和 55 年度に扮いては 356 千 $k l$ (全製成 数量の $29.8 \%$ ) で, 昭和 50 年度の $68.2 \%$ となって
いる。

次に, 未納税移出数量割合別の場数, 未納税移出数 量, 1 場当り未納税移出数量の推移をみると第 2 表のと おりである。

未納税移出数量の方が多いいわゆる未納税移出化存 している製造場は, 昭和 48 年度においては 2,315 場で あったのが, 昭和 55 年度は 1,634 場であって 681 場 減少している。

未納税移出数量割合別の未納税移出数量をみると, (1) 製成数量と末納税移出数量は必らずしも対応関係にない こと（期間のずれ），(2)こ数年業界全体として生産調

第 1 表 未納税移出数量等の推移

\begin{tabular}{|c|c|c|c|c|c|c|c|}
\hline \multirow[b]{2}{*}{ 年 度 } & \multicolumn{2}{|c|}{ 全製造場 } & \multicolumn{3}{|c|}{ 未納税移出のあるもの } & \multirow{2}{*}{$\frac{\text { 割 }}{(1) /(3)}$} & \multirow{2}{*}{$\frac{\text { 合 }}{\text { (2) /(5) }}$} \\
\hline & 場 (1) & 製成数量 & 埸 (3) & 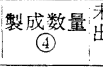 & $\begin{array}{l}\text { 本納税移 } \\
\text { 数量 } \\
\text { (5) }\end{array}$ & & \\
\hline 48 & $3,351^{\text {場 }}$ & $\begin{array}{r}\mp \mathrm{k} l \\
1,422\end{array}$ & $2,565^{\text {場 }}$ & $\begin{array}{l}4 \mathrm{kl} \\
957\end{array}$ & $\begin{array}{c}\mp \mathrm{F} l \\
516\end{array}$ & 76.5 & 36. ${ }^{\circ}$ \\
\hline 49 & 3,285 & 1,422 & 2,440 & 904 & 491 & 74.3 & 34.5 \\
\hline 50 & 3,238 & 1,364 & 2,334 & 879 & 522 & 72.1 & 38.3 \\
\hline 51 & 3,222 & 1,240 & 2,245 & 768 & 497 & 69.7 & 40.1 \\
\hline 52 & 3,193 & 1,301 & 2,209 & 786 & 454 & 69.2 & 34.9 \\
\hline 53 & 3,152 & 1,219 & 2,090 & 717 & 435 & 66.3 & 35.7 \\
\hline 54 & 3,103 & 1,182 & 2,003 & 662 & 409 & 64.6 & 34.6 \\
\hline 55 & 3,044 & 1,194 & 1,844 & 640 & 356 & 60.6 & 29.8 \\
\hline
\end{tabular}

第 2 表 未納税移出数量割合別，未納税移出数量等

\begin{tabular}{|c|c|c|c|c|c|c|c|c|c|c|c|c|}
\hline \multirow{2}{*}{ 年 度 } & \multicolumn{3}{|c|}{$80 \%$ 以上 } & \multicolumn{3}{|c|}{$80 \%$ 未満～ $60 \%$ 以上 } & \multicolumn{3}{|c|}{$60 \%$ 未满～ $40 \%$ 以上 } & \multicolumn{3}{|c|}{$40 \%$ 末 满 } \\
\hline & 場 数 & 数 量 & $\begin{array}{l}1 \text { 場当り } \\
\text { 数量 }\end{array}$ & 場 数 & 数 量 & $\mid \begin{array}{c}1 \text { 場当り } \\
\text { 数量 }\end{array}$ & 場 数 & 数 量 & $\begin{array}{l}1 \text { 場当り } \\
\text { 数量 }\end{array}$ & 埸 数 & 数 量 & $\begin{array}{l}1 \text { 埸当り } \\
\text { 数量 }\end{array}$ \\
\hline 48 & $578^{\text {場 }}$ & $221 \underset{(46.5)}{千 \mathrm{k} l}$ & $382^{\mathrm{k} l}$ & $543^{\text {場 }}$ & $119 \underset{(25.0)}{千 \mathrm{k} l}$ & $219^{k l}$ & $500^{\text {場 }}$ & $81^{\text {千 } \mathrm{k} l}$ & $163^{\mathrm{k} l}$ & $694^{\text {埸 }}$ & $\underset{55}{千 \mathrm{k} l}$ & $79^{\mathrm{k} l}$ \\
\hline 49 & 537 & $178(39.5)$ & 332 & 565 & $136(30.1)$ & 241 & 486 & 81 & 165 & 658 & 56 & 86 \\
\hline 50 & 737 & $271(55.8)$ & 373 & 468 & $101(20.9)$ & 217 & 420 & 66 & 157 & 559 & 47 & 84 \\
\hline 51 & 850 & $297(64.1)$ & 350 & 401 & $79(17.0)$ & 196 & 339 & 51 & 150 & 499 & 37 & 74 \\
\hline 52 & 560 & $212(50.2)$ & 378 & 473 & $103(24.4)$ & 218 & 405 & 61 & 151 & 601 & 46 & 76 \\
\hline 53 & 717 & $248(60.8)$ & 346 & 367 & $75(18.5)$ & 205 & 313 & 47 & 151 & 537 & 37 & 69 \\
\hline 54 & 668 & $254(66.7)$ & 380 & 311 & $53(14.1)$ & 173 & 310 & 39 & 125 & 504 & 35 & 68 \\
\hline 55 & 422 & $187(56.1)$ & 443 & 349 & $66(18.9)$ & 189 & 318 & 44 & 137 & 545 & 37 & 67 \\
\hline
\end{tabular}

（注） 1. この表は，末納税移出入がともにある場合は，末納税移出数量の方が多い製造場を掍げるとともに，差引未納税移出数量を掍げたもので 2. 「数量」欄の（）畫は全体に占める割合である。 
第 3 表 未納税移入数量割合別未納税移入数量等

\begin{tabular}{|c|c|c|c|c|c|c|c|c|c|c|c|c|}
\hline \multirow{2}{*}{ 年 度 } & \multicolumn{3}{|c|}{$44.4 \%$ 以上 } & \multicolumn{3}{|c|}{$44.3 \sim 37.5 \%$} & \multicolumn{3}{|c|}{$37.4 \sim 28.6 \%$} & \multicolumn{3}{|c|}{$28.6 \%$ 末澫 } \\
\hline & 場 数 & 数 量 & $\begin{array}{l}1 \text { 場当り } \\
\text { 数量 }\end{array}$ & 場 数 & 数 量 & $\begin{array}{l}1 \text { 場当り } \\
\text { 数量 }\end{array}$ & 場 数 & 数 量 & $\begin{array}{l}1 \text { 場当り } \\
\text { 数量 }\end{array}$ & 場 数 & 数 量 & $\begin{array}{l}1 \text { 場当り } \\
\text { 数量 }\end{array}$ \\
\hline 48 & $54^{\text {場 }}$ & $\underset{392}{\mp \mathrm{k} l}$ & $7,258^{\mathrm{k} l}$ & $16^{\text {場 }}$ & ${ }_{21}^{千 \mathrm{k} l}$ & $1,295^{\mathrm{k} l}$ & $36^{\text {埸 }}$ & ${ }_{14}^{千 \mathrm{k} l}$ & $388^{\mathrm{k} l}$ & $272^{\text {場 }}$ & ${ }_{34}^{\mp \mathrm{k} l}$ & $125^{\mathrm{k} l}$ \\
\hline 49 & 41 & 356 & 8,694 & 10 & 16 & 1,589 & 39 & 28 & 712 & 255 & 33 & 131 \\
\hline 50 & 51 & 386 & 7,560 & 17 & 39 & 2,270 & 28 & 11 & 390 & 248 & 29 & 118 \\
\hline 51 & 51 & 386 & 7,568 & 15 & 19 & 1,274 & 21 & 11 & 525 & 227 & 25 & 109 \\
\hline 52 & 46 & 347 & 7,533 & 11 & 13 & 1,211 & 18 & 19 & 1,070 & 267 & 27 & 100 \\
\hline 53 & 54 & 327 & 6,047 & 10 & 24 & 2,422 & 19 & 8 & 412 & 238 & 33 & 138 \\
\hline 54 & 47 & 304 & 6,462 & 12 & 10 & 864 & 16 & 28 & 1,735 & 252 & 25 & 98 \\
\hline 55 & 42 & 253 & 6,030 & 15 & 9 & 1,236 & 16 & 18 & 1,116 & 233 & 28 & 121 \\
\hline
\end{tabular}

（注）「数量」櫊の（）書は，合計数量に占める割合である。

整を行ってきたこと，から一つの傾向をつかむことはで きないが，未納税移出数量の割合が $60 \%$ 以上の、納税 移出を主体とする製浩場 (昭和 48 年度は末納税移出製 造場の $48.4 \%$, 昭和 55 年度は $47.2 \%$ ) で, 全体の未 納税移出数量の $75 \%$ 以上を占めている(最も高いのは 昭和 54 年度の $80.8 \%$ )。

1. 製造場当りの未納税移出数量をみると, 来納税移出 数量割合が大きくなるほど未納税移出数量も多くなっ ており,また, 最近の傾向としては, 来納税移出数量割 合 $80 \%$ 以上で未納税移出数量が堌加しているのが注目 される。

\section{（2）未納税移入の推移}

未納税移入数量割合 (未納税移入数量/製成数量十東 納税移入数量) 別, 未納税移入場数, 未納税移入数量の 推移は第 3 表のとおりである。

未納税移入場数は, 每年隇少傾向にあって昭和 48 年 度において 378 場であったものが, 昭和 55 年度は 306 場となっている。

未納税移入数量の割合が $37.5 \%$ (製成数量の $60 \%$ ) 以 上の製造場は, 昭和 48 年度に打いては 70 場であり, こ の 70 場で全体の未納税移入数量の $89.6 \%$ を占めてい: が, このランクの製造場も減少傾向を辿り, 昭和 55 年 度においては 47 場で, その移入数量は全体の $85.5 \%$ を占めている。この状沉からみると, 未納税移入数量は 少数の大手製造場に集中していると同時に，最近に拀い ては，自製酒比率を徐々涪めてきていることがうかが える。

\section{（3）未納税取引の減少の背景}

以上の上うに, 未納税取引は, 昭和 50 年度以降取引 数量のみならず, 移出製造場, 移入製造場ともに隇少を 辿っているが，その原因 (背景) としては, 次のことが あげられる。

1 清酒の楞税移出数量は, 昭和 50 年の 1,770 千 $\mathrm{k} l$ (9,814 千石)を最高として, その後減少傾向を辿り,
第 4 表 上位 100 社の課税移出数量シェアの推移

\begin{tabular}{|c|c|c|c|c|c|}
\hline 分 & 年 度 & 特 級 & 1 級 & 2 級 & 計 \\
\hline \multirow{3}{*}{ 上位 10 社 } & 52 & $67.6 \%$ & $49.5 \%$ & $8.9 \%$ & 35.1 \\
\hline & 53 & 68.0 & 49.7 & 10.8 & 35.5 \\
\hline & 54 & 67.3 & 49.1 & 10.5 & 35.1 \\
\hline \multirow{3}{*}{ 上位 50 社 } & 52 & 87.3 & 68.9 & 31.5 & 55.4 \\
\hline & 53 & 87.5 & 68.8 & 33.0 & 55.9 \\
\hline & 54 & 87.1 & 67.9 & 32.7 & 55.3 \\
\hline \multirow{3}{*}{ 上位 100 社 } & 52 & 91.0 & 75.0 & 44.7 & 64.1 \\
\hline & 53 & 91.3 & 75.0 & 46.1 & 64.6 \\
\hline & 54 & 91.0 & 74.0 & 45.9 & 64.0 \\
\hline
\end{tabular}

第 5 表 か動率の推移

\begin{tabular}{llll|c|c|c|c|c}
\hline \hline 区 分 & 事業 年度 & 50 & 51 & 52 & 53 & 54 \\
\hline 全 国 & 平 & 均 & $(\%)$ & 74.9 & 67.9 & 71.2 & 66.8 & 64.8 \\
製造数量 $5,000 \mathrm{k} l$ 超の平均 & $(\%)$ & 70.0 & 67.7 & 71.5 & 67.8 & 68.5 \\
\hline
\end{tabular}

昭和 55 年は 1,559 千 $k l(8,675$ 千石) で，この間に年 率 $2.5 \%$ の減少を示している。(昭和 50 年の課税移出 数量は, 昭和 51 年 1 月の酒税増税飞伴う佮需の影響 を受けているので，消費の実勢としては隇少率は年率 $2.5 \%$ より小さと認められる。)

ところで, 未納税移入数量の多い大手企業の課税移出 数量はどうかについてみると, 昭和 50 年度までは, 大 手企業の伸び率は全国の伸び率を上回り, 着実にシェア をアップさせてきたが，第 4 表のと㧍り，最近に㧤いて は, 大手企業も全国合計とほ济同様の傾向であって, 上 位 100 者のシェアは各級に亘りほぼ横ばいないしダウン の傾向になる。

口一方，大手企業の生産面住つてみると，第 5 表 のと打り, 製造設備のか動率は, 昭和 54 事業年度に拉 いても $68.5 \%$ であって, 相当程度の製造余力がある。 このため, 次の八, 二のからみもあって, 大手企業は可 能な限り, 自製酒を增加させたいとする意向が強い。

八また、コスト面をみると，自製酒原価と末納税移 入酒原価との差は, 第 6 表のと㧍り, 昭和 50 事紧年度 
第 6 表 清酒 (20度) $1 \mathrm{k} l$ 当りの原価

\begin{tabular}{|c|c|c|c|c|c|c|}
\hline 事業年 & 50 & 51 & 52 & 53 & 4 & $54 / 50$ \\
\hline (1) & $\begin{array}{r}\mathrm{P} \\
171,870\end{array}$ & & 184, 170 & $\begin{array}{r}\text { 男 } \\
185,060\end{array}$ & & 11. \\
\hline j & 070 & 19 & 210,840 & 2 & 214,150 & 9 \\
\hline $\begin{array}{c}\text { 原 価 差 } \\
\text { (3)/(1) }\end{array}$ & $\begin{array}{r}7,200 \\
4.2 \%\end{array}$ & $\begin{array}{l}15,520 \\
8.5 \%\end{array}$ & $\begin{array}{c}26,170 \\
14.2 \%\end{array}$ & $\mid \begin{array}{c}26,820 \\
14.5 \%\end{array}$ & $\begin{array}{c}22,080 \\
11.5 \%\end{array}$ & 306.7 \\
\hline
\end{tabular}

に执いては，4.2\%(移入酒の方が高い)にとどまってい たが，徐々汇差が大きくなり昭和 53 事業年度において は，14.5\% 高となった。このようにコスト的にも未納 税移入酒は不利となっている。製造余力が相当程度ある 現在，操業度上昇によるコストダウンを考虑すると，現 有設備の有効利用までは自製酒を増産したいと望むのは 当然ではなかららか。

二 更には，未納税移入酒と自製酒をブレンドするこ とについて，一般の理解が十分でない点である。

清酒業界は，清酒の表示に関する公正競争規約を締結 すべく，その案を公正取引委員会に提出したが，その容 議の過程における公聴会において，消費者団体代表から 「産地表示をすべきである」との強い意見が出された。ま た，本年 1 月朝日新聞が大手企業の自製酒比率をとりあ げているが，いすれも，未納税移入酒と自製酒を混合 し，その事実を明確にしないで一つの銘柄で肢売してい ることに問題があるというものである。これは未納税移 入酒は品質的に劣る，未納税移入酒と自製酒をブレンド することは，自製酒そのものよりも品質的炕劣るという 認識によるものにほかならない。

清酒の未納税取引と清酒のブレンドについて，一般の 理解が十分でなくむしろ誤った認識があり，今後，再度 問題にされかねない状況にあるとすれば，清酒はイメー ジ商品であるだけに大手企業は自製酒比率を可能な限り 高めようとするのは当然であろう。

\section{2. 未納税取引の今後の環境}

\section{（1）清酒の需給状況}

未納税取引数量は清酒の需給関係に大きく影響を受け るので, 最近の清酒の需給関保はどうなっているかにつ いてみると第 7 表のと打りである。

最近に怙ける清酒の課税移出数量は, 期間のとり方に よって六きな差が生じており，どの数字が実勢か判断つ きか㸚るものがある。これは，昭和 52 年 6 号にコス トアップ値上げ, 昭和 53 年 5 月に増税, 昭和 55 年 2 月にコストアップ值上げ，昭和 56 年 5 月に增税と 続いて扣り，その前後に仮需要とその反動が現われてい るためである。そこで，ここでは，過去の実績と最近の 状況を考慮して, 昭和 55 酒造年度の課税移出数量は
第 7 表 清酒の需給状沉

（単位：供給ベース，千石，\%)

\begin{tabular}{|c|c|c|c|c}
\hline \hline 区分 & 53 & 54 & 55 (見造) & 56 (想定) \\
\hline 期 首 在 庫 & $8,227(110.6)$ & $8,088(98.3)$ & $7,500(92.7)$ & $7,300(97.3)$ \\
製 成 数 量 & $8,531(92.0)$ & $8,193(96.0)$ & $8,400(102.5)$ & $8,500(101.2)$ \\
課税移出数量 & $8,670(102.2)$ & $8,781(101.3)$ & $8,600(97.9)$ & $8,670(100.8)$ \\
期 末 在 庫 & $8,088(98.3)$ & $7,500(92.7)$ & $7,300(97.8)$ & $7,130(97.7)$ \\
期末在庫割合 & 11.0 月 & 10.5 月 & 10.1 月 & 9.9 月 \\
\hline
\end{tabular}

（注） 1. 昭和56酒造年度の課税移出数量については，次の上5に， 会計年度, 酒造年度,楚年のいずれの 3 か年平均値も 8,670 千石程度であるので,これが最近の清酒の寒勢とみた。 過去か 3 年の課税移出数量 (単位: 千石)

\begin{tabular}{|c|c|c|c|c|}
\hline & 53 & 54 & 55 & 3 年平均 \\
\hline 会計年 度 & 8,678 & 9,154 & 8,168 & 8,667 \\
\hline 酒 造 年 度 & 8,670 & 8,783 & 8,600 & 8,684 \\
\hline 歴 年 & 8,611 & 8,770 & 8,643 & 8,675 \\
\hline
\end{tabular}

2. 期末在庫は，10か月弱が適正とみた。

8, 600 千石，昭和 56 酒造年度の㗚税移出数量は 8,670 千石と単純に想定したが，これを基にして，昭和 56 酒 造年度の適正生産数量を試算すると 8,500 千石程度で あって，横ばいないし微增にとどまる。

このような状況のなかで, 大手企業は, 課税移出数量 は伸びなやんでいるものの，製造余力があること及びニ ス卜低減を図る必要があること等から，ある程度の增産 を目論む企業が多いと考えられるので一般的にはこれら 大手企業と取引する未納税移出企業の注文生産数量は隇 少することになると見込まれる。

未納税取引は個々の企業によって事情が異なってお り，一概に論しられない面があるが，昭和 54 年度及び 昭和 55 年度の取引実䋶が示すとおり, 未納税取引の取 引先数及び取引数量が減少しているなかで，未納税移出 数量割合 $80 \%$ 以上のところでは，1製造場当りの取引 数量は增加して扣り経済合理性を泊求する形で選別が進 められていることを示している。

昭和 56 酒造年度の生産数量が 8,500 千石程度にと どを机ば，期末在庫はほぽ 10 か月程度となって適正在 庫は維持できるであろらから，昭和 57 酒造年度以降に おいては, 課税移出数量に見合った生産が可能となる。 ところで, 最近, 清酒の需要振興に業界あげて努力して いるとはいらものの速効は期待できず，当分の間は横ば いないし微減の傾向で推移するのではないかと考学られ る。従って昭和 57 酒造年度以降の生産数量は 8,600 干 石〜 8,700 千石程度は期待できるものの，それ以上は望 めない上らに思われる。

このような状況のなかで，すでに大手企業のシェアア ップは昭和 50 年度で止っており，その後は横ばいない 乙微減の傾向であり，更には最近の状沉をみると地酒の 見直しの傾向が表面化しつつある点を考慮すると，大手 企業自身も極めて蕨しい環境下にあることが容易に推察 
されるところである。以上の点を考慮すると末納税取引 数量は今後当分の間 (大手企業に製造余力がある間) は 減少を続けるものと見込まれるので，大手企業傘下の未 納税移出企業は, この点を十分見極めた対応が必要であ ると考兄られる。

\section{（2）転廃給付金制度等の打切り}

以上のように, 末納税取引の環境の厳しさは既に数年 前から予見されており, やむを得ずして清酒業界から撤 退せざるを得ない企業も多く出るものと予想されたこと から,これらの者の救済の一助にするために, 清酒製造

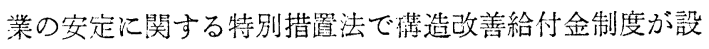
けられている。また，この制度だけでは十分でないた め, 䔝界の相互協力の観点から移入企業が取引を停止す る移出企.業に対して相灾の見舞金を支給する方向で相互 の話し合いが進められてきている。

以上の措置は, いずれも昭和 56 年 11 月までに転廃 業する者に対するもので, 現在のところ, 昭和 57 年度 以降法察湴する者に対する助成策等は一切なく, ま た，助成策等を橉じられる見込みも極めて薄い情勢にあ る。

以上の状沇から, 大手末納税移入企業としても, 長期 的に取引継続の見込みのない企業に対しては, 取引停止 等について積極的にアピローチすることになるであろ う。また，未納税移出企業としても取引先移入企業の今 後の方針等を確かめ, 更には自己企業の進路を十分見挭 めて重大な決意をしなけ礼ばならない年になるのではな いかと考学られる。

\section{3. 未納税取引の今後のあり得べき方向}

\section{（1）清酒の需要振興とブレンド効果についての正し (認識の普及}

清酒需要の停㴖 (又減少) が統く限り, 未納税取引 数量も減少し, 攻引先の選別も厳しくならざるを得な い。しかし, 清酒の需要が回復し増加に䎐じ, 未納税移 入企業の課税移出数量も增加するといらことになれば, それ相応に未納税移入数量も增加するであろらから，そ れだけ末納税移出企業も救われることになる。従って, 蕉本的には清酒需要の振興対策が何よりも重要である。

また，前述のと抢り，未納税移入酒は品質的に悪であ るといった風潮が一般にあるため, 産地表示を問題にさ れているが，この問題が解決しない限り，末納税移入企 業としては可能な限り自製酒比率を高める努力をするで あろうし，その結果として，末納税移出企業は圧迫を受 けることとなる。

ところで, 清酒心酒質は, 同一産地であっても, 傅用 する米，そつ工場の水質，製造技術等によって器なり，
また，同一工場であっても仕込ごとに酒質が微妙に寒な るし, 一般消費者が唎分けることが出来るほど, 清酒に 産地による特徵があるとは思劣ない。しかしながら, 清 酒業界においては，過去あるいは現在なお，銘醸地 $\bigcirc$ 県産酒, ○○先一本, 等と産地をセールスポイントにし てきた面がありこれが消費者に誤った認識をらえつけ る結果となっているのではないかと思われる。

また，清酒のブレンドの必要性とその効果について は, (1)清酒成分の均一化, (2)酒質の均一化, (3)酒質》向 上があげられ，この点について一般消費者の認識が不十 分ではないかと思われる。

最近, 未納税取引は注文生産制度によって, 未納税移 入企業は発注に祭し品質，規喿及びその製造方法につい て細部にわたり明細な指示をし，かつ技術指導を行って いる企業が多くなっており, 未納税移入企業の酒質に合 致したものが取引されているのが実態である。これらの 未納税移入酒と自製酒の酒筫等を総合的飞勘案して，そ の銘柄の酒質になるようブレンドして出荷されているの が実状である。

以上の点を, もっと積極的保 P Rする必要があるので はないだろらか。

清酒の製造者数は多くしかも全国㳻在して少り，そ れぞれの企業が戦しい服売䟽争を続けている。その結 果, 各企業は様々な販売戦略を考克, 酒質とは直接関係 のないものであっても，それを宣伝に使用してきている ものがいくつかある。また, 酒質には直接関䋆のないこ とであっても，○○酒造は○○を使用しているから酒質 が悪い等と悪宣伝をすることも度々である。これらのこ とから, 一般消費者の多くは, 清酒酒ついての十分な忍 識が得られず，むしろ䛊った理解をしている部分が多く あり,これが, 清酒の需要振與に悪影響を及ぽしている 面があるのではないだろうか。

今や，清酒業界は業界内での中傷を繰り返しているほ ぞ余裕があるとは思えない。清酒企業が一丸となって, ウイスキー,ビールに対抗する必要があるうし, 清酒の イメージを高める統一したセールスポイントが必要にな っていると思われる。

\section{(2) 未納税取引の安定化}

未納税取引数量は当分の間減少を辿ると見込まれる が, 大手末納税移入企業は現在製造余力があるとはいっ ても自製酒比率が相当に低いので, 相当長期に亘り, 相 当多量の未納税移入酒に依存しなければならないと認め られる。従って, 長期的観点からすれば, 移入企業にと って優良移出企業の育成と安定的取引数量の確保が必要 であり, また, 䔟出企業にとっては, 経営の安定と発展 の面から㱼引の安定が是非とも必要である。 
ところで, 未納税取引の現状は，(1末納税取引数量の 減少傾问, (2)未納税移出企業は数が多くそのら光先行不 安であること, 等から未納税移入企業が優位に立ってい る。このため, 次のよらな問題が生じている。

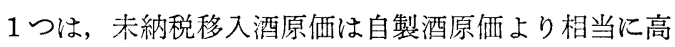
く未納税移入企業にとっては，買入洒格を出来るだけ 安くなることを望んでいるが，未納税移出型企業の昭和 55 年度における決算状況をみると, $41.6 \%$ の企業が赤 字であり， $25.4 \%$ (赤字を含めると $67.0 \%$ ) の企業が税 引前利益 50 万円来満であって, 多数の企業が末納税取 引は採算が合っていないことを示している。

$2 つ$ つ未納税移入酒はコスト的に自製酒より不利と はいっても，全量自製酒とするための設備投資とそれに よる製造コストを考慮すればが，当面，未納税移入酒の 方が相当にメリットが大きいと考光られる。この点と末 納税移出企業のコストを考慮に入れれば，現在の圭納税 取引価格は安いのではないかと思われる。この安く仕入 れた部分を企業内に蓄積するのであれば，清酒業界に悪 影響を及ぼすといらことはないので，未納税移出企業の 経営面を除き，特に問題にすることはない。

しかし，大手企業であっても，販売市場に批いて相当 多額のリベート等を支出しているのが実態であり，この 原資の大部分は未納税移入酒の買い入価格にあるとみる ことができる点に問題がある。なぜなら，大手企業の多
額のリベートの支出によって，銘柄力の弱い中小メーカ 一は大手企業以上のリベートの支出を余儀なくして拝 り，これが，清酒業界全体の体質弱体化をもたらしてい ると同時に, 清酒のコストアップ値上げのインターバル を早めている大きな要因ともなっている。

以上の点を考虑すると, 今後の未納税取引については 次の点に留意して行く必要があるのではないかと考克ら れる。

(1) 未納税移入企業は, 中長期的観点に方って未納税 取引の計画を明確にする。この場合, 品質, 立地, 規 模, 過去の取引実績あるいは取引先企業の意欲等を総合

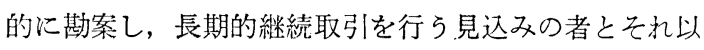
外の者に区分し，それを出来るだけ早い機会に取引先移 出企業に意思表示する必要がある。

(2) また，一般的に未納税移出企業の生産規模は小さ いため, コスト高となっているので，経済性を考虑した 場合には現有設備の有效利用を前提としての集約化が是 非とも必要であり，この集約化が可能な企業に対して は，未納税移入企業は積極的な支援が必要であろう。

(3) 取引価格については, ある程度の生産規模（中長 期的にみて存続を必要とする未納税移出企業の生産規 模）の未納税移出企業であれば，採算のとれる妥当な価 格にする必要がある。

（国税庁・酒税課） 